\title{
SEGREGATION OF NITRIC OXIDE SYNTHASE EXPRESSION AND CALCIUM RESPONSE TO NITRIC OXIDE IN ADRENERGIC AND NORADRENERGIC BOVINE CHROMAFFIN CELLS
}

\author{
M. J. OSET-GASQUE, ${ }^{*}$ S. VICENTE,* M. P. GONZÁLEZ,* L. M. ROSARIO† and \\ E. CASTRO $\ddagger$ \\ * Department of Biochemistry and Molecular Biology, Faculty of Pharmacy, \\ Complutense University of Madrid, E-28040 Madrid, Spain \\ $†$ Department of Biochemistry and Molecular Biology, Faculty of Veterinary Sciences, \\ Complutense University of Madrid, E-28040 Madrid, Spain \\ $\ddagger$ Center for Neurosciences of Coimbra, University of Coimbra, P-3049 Coimbra, Codex, Portugal
}

\begin{abstract}
Previous work has demonstrated that nitric oxide can be an important intracellular messenger in the regulation of neurosecretion in chromaffin cells. Since standard chromaffin cell cultures are mixed populations of noradrenaline and adrenaline producing cells, it would seem important to understand the functional differences between these individual components. The use of fluorescence imaging techniques for the recording of cytosolic calcium from single chromaffin cells together with the immunoidentification of individual cells with specific antibodies against tyrosine hydroxylase, $N$-phenyl ethanolamine methyl transferase and nitric oxide synthase, has allowed us to measure single-cell calcium responses in identified adrenergic, noradrenergic and nitrergic chromaffin cells, thus helping us to clarify the differential role of nitric oxide in the function of these chromaffin cell types. $53 \pm 2 \%$ of chromaffin cells were able to synthesize nitric oxide (nitric oxidesynthase-positive cells), these cells being mainly noradrenergic $(82 \pm 2 \%)$. Results indicate that nitric oxide donors such as sodium nitroprusside, molsidomine and isosorbide dinitrate evoke $\left[\mathrm{Ca}^{2+}\right]_{\mathrm{i}}$ increases in a $62 \pm 4 \%$ of chromaffin cells, the response to nitric oxide donors being between 30 and $50 \%$ of that of $20 \mu \mathrm{M}$ nicotine. Cells responding to nitric oxide donors were mainly adrenergic $(68 \pm 5 \%)$ although $45 \pm 9 \%$ of noradrenergic cells also gave $\left[\mathrm{Ca}^{2+}\right]_{\mathrm{i}}$ increasing responses. The distribution of nitric oxide responding cells between nitric oxide synthase-positive and negative was very similar in the whole population ( $63 \pm 5$ and $60 \pm 7 \%$, respectively), but these differences were more prominent when considering the distribution of nitric oxide response between noradrenergic and adrenergic nitric oxide synthase-positive cells; while $73 \pm 6 \%$ of adrenergic nitric oxide synthasepositive cells evoke $\left[\mathrm{Ca}^{2+}\right]_{i}$ increases by nitric oxide stimulation, only $35 \pm 11 \%$ of noradrenergic nitric oxide synthase-positive cells respond.

Taken together these results seem to indicate that (i) nitric oxide could act within adrenal medulla as both an intracellular and intercellular messenger; and (ii) noradrenergic cells seem to be specialized in nitric oxide synthesis while adrenergic cells with an endocrine function could mainly act as a target of neurosecretory action of this second messenger. (C) 1997 IBRO. Published by Elsevier Science Ltd.
\end{abstract}

Key words: nitric oxide, chromaffin cells, catecholamines, calcium, immunocytochemistry.

Nitric oxide (NO) is a short-lived, highly reactive radical, originally identified as both a mediator in vasodilatation $^{22}$ and an active agent in macrophage

§To whom correspondence should be addressed.

Abbreviations: AMCA, 7-amino-4-methyl-coumarin-3acetic acid; BSA, bovine serum albumin; $\left[\mathrm{Ca}^{2+}\right] \mathrm{i}$, intracellular free calcium concentration; ChAT, choline acetyltransferase; DABCO, diazabicyclo[2,2,2]octane; DMEM, Dulbecco's modified Eagle's medium; FITC, fluorescein isothiocyanate; HEPES, $N$-2-hydroxyethylpiperazine- $N^{\prime}$ 2-ethanesulphonic acid; ISDN, isosorbide dinitrate; nNOS, neural isoform of nitric oxide synthase; NO, nitric oxide; NOS, nitric oxide synthase; PBS, phosphatebuffered saline; PNMT, $N$-phenyl ethanolamine $N$ methyl transferase; SNP, sodium nitroprusside; $\mathrm{TH}$, tyrosine hydroxylase; TRITC, tetramethylrhodamine isothiocyanate. cytotoxicity. ${ }^{25}$ In addition NO has been shown to function as a central and peripheral neuronal messenger or putative neurotransmitter involved in crucial physiological events such as neurotransmitter release, ${ }^{13}$ long-term potentiation ${ }^{12}$ and gene transcription, ${ }^{11,31}$ as well as in the pathophysiological events underlying neurotoxicity. ${ }^{2,37}$

In central and peripheral neurons NO is synthesized from L-arginine by the neural isoform of nitric oxide synthase (nNOS), which is structurally, immunologically and functionally different from the isoforms expressed constitutively in vascular endothelial cells or upon induction in macrophages. ${ }^{18}$ The presence of this enzyme has been shown in different peripheral neural tissues by both biochemical analysis and immunofluorescence techniques. ${ }^{1}$ In 
these tissues NO plays its physiological functions by activation of a soluble guanylate cyclase resulting in formation of cGMP.

In the adrenal medulla, a tissue of ectodermic origin (as are neurons), the existence of a complete pathway L-arginine/NO/cGMP has been demonstrated. The presence of NOS has been shown in bovine chromaffin cells by both biochemical methods demonstrating the formation of L-citrulline from L-arginine $\mathrm{e}^{27,30}$ and by immunohistochemical methods using antisera raised against purified soluble $\mathrm{nNOS}^{3}$ or cytochemical techniques showing a specific staining for NADPH-diaphorase. ${ }^{27}$ By using these techniques its presence has been also assessed in adult rat adrenal gland in almost all choline acetyltransferase (ChAT)-positive fibres and ChAT/enkephalin preganglionic fibres running in the splanchnic nerves $^{16}$ and in small intra-adrenal non-cholinergic/ non-adrenergic ganglion neurons which express vasoactive intestinal polypeptide-like immunoreactivity that are scattered between chromaffin cells." In human adrenal medulla, immunoreactivity for NOS has also been demonstrated in neurons, nerve fibres and chromaffin cells, co-localizing with substance $P$ only and not with neuropeptide $Y$ and somatostatin. ${ }^{15}$ The location of NOS in distinct structural compartments of the rat and human adrenal medulla indicates that NO is produced in different cell types and may reflect a differential role of this messenger system in autonomic control of adrenal gland function.

Concerning the role of $\mathrm{NO}$ in the regulation of adrenal medulla function previous work indicates that nitrergic compounds ${ }^{7}$ or pure $\mathrm{NO}^{27}$ activate basal and inhibit nicotine-evoked catecholamine secretion. However, while there is general agreement with the fact that NO pure gas, ${ }^{27}$ NO-generating compounds and cGMP $P^{29.32,33}$ decrease both catecholamine secretion and intracellular free calcium concentration $\left(\left[\mathrm{Ca}^{2+}\right]_{i}\right)$ increases evoked by depolarizing stimuli like acetylcholine, nicotine and high $\mathrm{KCl}$, there are contradictory results concerning the effect of NO on basal catecholamine secretion and $\left[\mathrm{Ca}^{2+}\right]_{i}$ since some authors failed to find any effect of $\mathrm{NO}$ on catecholamine secretion by itself. ${ }^{24.29 .32 .33}$ In disagreement with these positive observations, Marley et al $^{20}$ failed to find specific staining for NADPHdiaphorase and nNOS in adrenal medullary chromaffin cells and nerve fibres or any effect of NO in adrenaline and noradrenaline secretion evoked by electric field stimulation, concluding that NO does not play a direct role in the acute regulation of adrenal catecholamine secretion.

All these results show that the effect of NO on the function of chromaffin cells is more complex than it previously seemed and it is far from being clear. A major source of uncertainty that may explain, at least in part, these conflicting results, may be the known cellular heterogeneity of bovine adrenal medulla and chromaffin cell cultures. ${ }^{10,23}$ Functionally different responses to histamine and angiotensin $\mathrm{II}^{5.26} \mathrm{ATP}^{4}$ and $\mathrm{Ca}^{2+.35}$ were demonstrated among adrenergic and noradrenergic or ganglionar cells co-existing in these mixed cultures. So, given this heterogeneity it seems very important to investigate the possible functional differences between these cellular types with respect to NO action. For example, it is important to know if NO-evoked responses are limited to a unique population of noradrenergic or adrenergic chromaffin cells and if they correspond to NOproducing $\left(\mathrm{NOS}^{+}\right)$or non-producing (NOS ) chromaffin cells.

Since a key messenger in the neurosecretory function of chromaffin cells is $\mathrm{Ca}^{2+}$, whose signalling pathways are deeply involved in these as well as many other neuronal processes, ${ }^{21}$ we have combined the fluorescence imaging techniques for the recording of cytosolic free calcium from single chromaffin cells with the immunoidentification of individual cells using specific antibodies against tyrosine hydroxylase (TH), phenyl ethanolamine $N$-methyl transferase (PNMT) and nNOS, in order to be able to ascribe single cell calcium responses to identified chromaffin cells. It has helped us to clarify the differential role of $\mathrm{NO}$ in the function of adrenaline and noradrenaline secreting cells as well as in NO-producing cells.

\section{EXPERIMENTAL PROCEDURES}

\section{Cell culture}

Bovine chromaffin cells were obtained essentially in the same way as described previously. ${ }^{8.17}$ Briefly, after digestion by retrograde perfusion with collagenase the medullary tissue was collected, disgregated and chromaffin cells purified in a Percoll density gradient. The cells were plated onto $16 \mathrm{~mm}$ round coverslips coated with poly-L-lysine. Chromaffin cells were maintained under a $5 \% \mathrm{CO}_{2} / 95^{\prime \prime} / /$ air humidified atmosphere at $37^{\circ} \mathrm{C}$ in a $1: 1$ mixture of Dulbecco's modified Eagle's medium (DMEM)/F-12 medium supplemented with $15 \mathrm{mM}$ HEPES, $25 \mathrm{mM} \mathrm{NaHCO}, 5 \%$ inactivated foetal calf serum, penicillin and streptomycin. Cells were typically used between days 2 and 6 after plating.

\section{Microfluorescence set-up}

The $\left[\mathrm{Ca}^{2+}\right]_{i}$ was measured with the fluorescent probe Fura-2. The coverslips containing the cells were washed in physiological saline containing (in $\mathrm{mM}$ ): $120 \mathrm{NaCl}, 5 \mathrm{KCl}$, $25 \mathrm{NaHCO}_{3}, 2 \mathrm{CaCl}_{2}, 1 \mathrm{MgCl}_{2}$ and 10 glucose. The solution was constantly gassed with $95 \% \mathrm{O}_{2} / 5 \% \mathrm{CO}_{2}$ for a final $\mathrm{pH}$ of 7.4. Chromaffin cells were loaded with $2.5 \mu \mathrm{M}$ Fura2/AM for $45 \mathrm{~min}$ at $37^{\circ} \mathrm{C}$ in this medium supplemented with $1 \%$ bovine serum albumin (BSA). After washing, the coverslip was glued to the bottom of a small (approx. $100 \mu \mathrm{l})$ perifusion chamber and placed in the stage of a Nikon Diaphot TMD microscope. The cells were continuously perifused (approx. $1.5 \mathrm{ml} / \mathrm{min}$ ) with gassed physiological saline. The drugs were applied for short periods $(15-60 \mathrm{~s})$ dissolved in the perifusion medium with the aid of a four-way stopcock.

\section{Measurement of $\left[\mathrm{Ca}^{2+}\right]_{i}$ by video imaging}

The fluorescence changes were recorded with a multiple excitation MagiCal imaging system (Applied Imaging, U.K.). Chromaffin cells were alternately excited at $340 \mathrm{~nm}$ and $380 \mathrm{~nm}$ by means of a stepping filter wheel and the epifluorescence optics of the microscope. Emitted fluor- 
escence collected with a $20 \times$ objective was driven to a Photonics Science SIT camera after passing through a $510 \mathrm{~nm}$ bandpass filter. Eight frames (approx. $100 \mathrm{~ms}$ exposure) were averaged to produce each image. Alternative excitation, image capture and processing were controlled by a single processor in the MagiCal system. Image analysis was performed with MagiCal software and custom-made programs (developed by E.C., details available on request). Essentially, background fluorescence at each wavelength (obtained from a field devoid of cells in each coverslip) was subtracted and fluorescence images ratioed on a pixel-bypixel basis. Ratio data were stored as 8-bit pseudocoloured images. A contour was drawn around each cell in a field and the averaged ratio value of pixels inside each contour evaluated at each time point, in order to obtain ratio vs time plots for all cells.

\section{Immunocytochemical identification of chromaffin cells}

To study the distribution of NOS, the cells were double immunostained with antibodies against NOS (mouse monoclonal anti-NOS) and either TH or PNMT (rabbit polyclonals anti-TH and anti-PNMT). Briefly, cells were fixed for $2 \mathrm{~min}$ in ice-cold $1: 1$ acetone:methanol mixture. After blocking in phosphate-buffered saline (PBS) with $3 \% \mathrm{BSA}$ $0.1 \%$ Triton $\mathrm{X}-100$, the preparation was incubated with primary antibodies (mouse anti-NOS $1: 100$, rabbit anti-TH or anti-PNMT 1:500) for $1 \mathrm{~h}$ at room temperature. After washing in $0.1 \%$ Triton X-100, secondary antibodies were added [fluorescein isothiocyanate (FITC)-labelled goat anti-mouse IgG and tetramethylrhodamine isothiocyanate (TRITC)-labelled goat anti-rabbit IgG at 1:200] and incubated for another hour.

To identify the cells responding to NO donors, triple labellings with mouse anti-NOS, rabbit anti-PNMT and mouse anti-TH (monoclonal) were performed in the same coverslips used for $\left[\mathrm{Ca}^{2+}\right]_{i}$ measurements. Once the $\left[\mathrm{Ca}^{2+}\right]$ experiments had been performed the cells were fixed with $50 \%$ acetone: $50 \%$ methanol $(\mathrm{v} / \mathrm{v})$ for $1-2 \mathrm{~min}$ at $4^{\circ} \mathrm{C}$, followed by freezing and storage at $-20^{\circ} \mathrm{C}$ until processing. For the immunofluorescence assay, the fixed coverslips were thawed by placing them in ice-cold 50\% acetone:50\% methanol and warmed until at room temperature; all the following procedures were performed at this temperature. The preparation was first processed as for double labelling using anti-NOS and anti-PNMT primary antibodies and FITC- and TRITC-secondary antibodies. After washing, the preparation was fixed again in 1:1 acetone:methanol in order to denaturalize the already bound mouse anti-NOS primary antibody ${ }^{14}$ and processed for labelling with mouse anti-TH (1:50) and 7-amino-4-methyl-coumarin-3-acetic acid (AMCA)-conjugated anti-mouse $\operatorname{IgG}(1: 100)$. The coverslips were mounted in 50\% glycerol in PBS containing $2.5 \%$ diazabicyclo[2,2,2]octane (DABCO) and digital images taken with the same MagiCal system used for $\mathrm{Ca}^{2+}$ experiments.

\section{Statistical analysis}

Fluorimetric data are expressed as mean \pm S.E.M. net ratio increases. Statistical comparisons between means were performed with a Student's $t$-test. Immunocytochemical data are expressed as number of cells counted and as proportion \pm S.D. of labelled cells vs total cells. S.Ds were calculated assuming a binomial distribution of counted cells. Comparisons between proportions in $2 \times 2$ tables were done with a $\chi^{2}$ test. $^{19}$ Table 3 was analysed with a bivariate ANOVA approach followed by $\chi^{2}$ tests of individual rows. ${ }^{34}$

\section{Materials}

Fura2/AM was from Molecular Probes (Eugene, OR, U.S.A.) and collagenase was from Boehringer Mannheim S.A. (Barcelona, Spain). DMEM and fetal calf serum were purchased from GIBCO (BRL, U.K.). Antibiotics were supplied by Flow Laboratories Ltd (Irvine, CA, U.S.A.). Sodium nitroprusside (SNP), isosorbide dinitrate (ISDN), molsidomine, BSA and anti-IgG-FITC and TRITC secondary antibodies were obtained from Sigma Chemical (Madrid, Spain). Mouse monoclonal anti-nNOS IgG was from Affinity Research Products Ltd (Nottingham, U.K.). Rabbit polyclonals anti-TH and rabbit anti-PNMT were from Eugene Technology International, mouse monoclonal anti-TH was from Boehringer Mannheim S.A. and AMCAconjugated anti-mouse IgG from Calbiochem (San Diego, CA, U.S.A.). All other reagents were from Merck (Darmstadt, Germany)

\section{RESULTS}

Nitric oxide donors evoke $\left[\mathrm{Ca}^{2+}\right]_{i}$ rises in a subpopulation of chromaffin cells

We observed rapid NO-donor induced changes in $\left[\mathrm{Ca}^{2+}\right]_{\mathrm{i}}$ in individual chromaffin cells (Fig. 1) with the aid of digital imaging fluorescence microscopy. The stimulation with these NO-donors produced different types of time courses, sometimes mono- and other times multi-phasic peaks. Representative time courses of changes in $\left[\mathrm{Ca}^{2+}\right]_{\mathrm{i}}$ in a few cells are shown in Fig. 1. The most common pattern of response encountered after $100 \mu \mathrm{M}$ molsidomine stimulation was a moderately increasing signal reaching a plateau (Fig. 1A). In contrast with $100 \mu \mathrm{M}$ SNP and ISDN the most common pattern of response was a transient (mono or biphasic) peak returning to basal levels after removing the compound (Fig. 1B, C). The resting $\left[\mathrm{Ca}^{2+}\right]_{i}$ was about $197 \pm 43 \mathrm{nM}$ in normal medium containing $2.5 \mathrm{mM} \mathrm{CaCl} \mathrm{Cl}_{2}$. Stimulation of cells with $100 \mu \mathrm{M}$ molsidomine, SNP or ISDN (the dose that doubled $\mathrm{NO}_{2}{ }^{-}$production levels), resulted in a net increase in the Fura-2 $\mathrm{F}_{340} / \mathrm{F}_{380}$ ratio of between 0.25 and 1.25 (about 50 and $450 \mathrm{nM}$ ), the more efficient agonist being molsidomine (Fig. 1A). The time course of calcium responses was different after challenging cells with $20 \mu \mathrm{M}$ nicotine. In this case, all the cells displayed rapidly increasing ratio transients that gradually decayed after washing the agonist and with peak heights larger than those obtained with NO-donors. The calcium increases in the case of NO-donors represented between 30 and $50 \%$ of the $\left[\mathrm{Ca}^{2+}\right]_{\mathrm{i}}$ rises obtained with $20 \mu \mathrm{M}$ nicotine in the same cells.

The frequency histograms showing the distribution of the three NO-donor increases in Fura-2 ratios $(\Delta$ ratio) in the whole chromaffin cell population are shown in Fig. 2. From the total chromaffin cell population the $57 \%$ responded to $100 \mu \mathrm{M}$ molsidomine, $36 \%$ to $100 \mu \mathrm{M}$ SNP and $37 \%$ to $100 \mu \mathrm{M}$ ISDN (Fig. 2). The maximal average ratio increase corresponded to molsidomine $(0.52 \pm 0.08$, mean \pm S.E.M.), followed by SNP $(0.45 \pm 0.04)$ and ISDN $(0.4 \pm 0.05)$, respectively. These parameters were collected from nine different experiments on a total of 125 chromaffin cells, among which 78 responded to NO-donors $(62 \pm 4 \%)$. 
A.

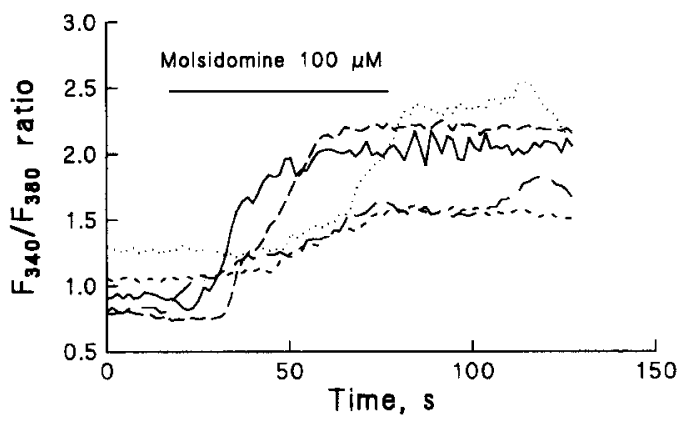

C.

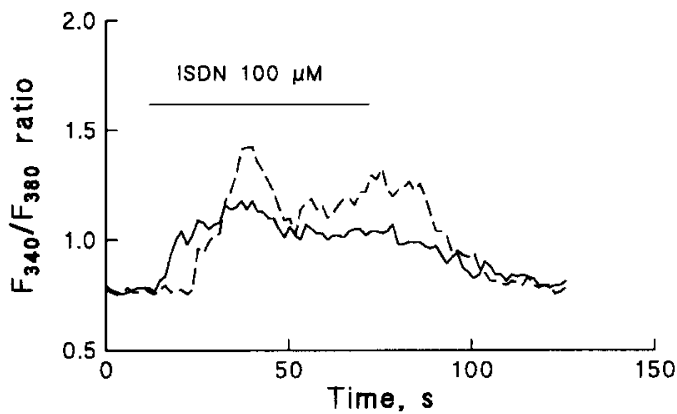

B.



D.

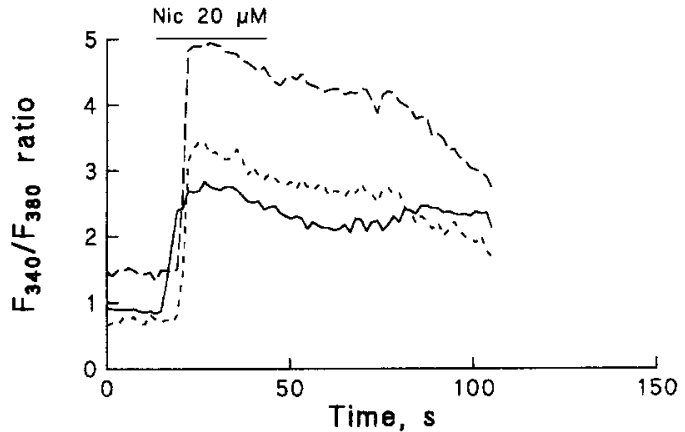

Fig. 1. Time courses of changes in $\left[\mathrm{Ca}^{2+}\right]_{\mathrm{i}}$ in individual chromaffin cells in response to stimulation with different NO-donors. Cells placed in a perifusion chamber in the stage of the microscope were imaged through a $20 \times$ fluor objective. The cells were stimulated with (A) $100 \mu \mathrm{M}$ molsidomine, (B) $100 \mu \mathrm{M}$ SNP and $(\mathrm{C}) 100 \mu \mathrm{M}$ ISDN for a $60 \mathrm{~s}$ period. Pairs of images of fields were captured at $1.5 \mathrm{~s}$ intervals and the $\mathrm{F}_{340} / \mathrm{F}_{380}$ ratio for each cell in the field was determined on a pixel by pixel basis as described in Experimental Procedures. Traces show representative examples of typical $F_{340} / F_{380}$ ratio responses of individual cells and correspond to different fields during different experiments. The lines show the application period of the different NO-donors.

Nitric oxide synthase synthesizing cells can be identified by nitric oxide synthase immunocytochemistry

The immunoidentification of chromaffin cells was carried out by treatment of fixed chromaffin cells with different specific antibodies against $\mathrm{TH}$, the rate-limiting enzyme for catecholamine biosynthesis (which stains the total chromaffin cell population), PNMT, the regulatory enzyme of adrenaline biosynthesis (marker of adrenergic population of chromaffin cells) and for nNOS, enzyme responsible for NO biosynthesis and marker of nitrergic cells. Noradrenergic cells were those stained by anti-TH but not by anti-PNMT antibodies.

Figure 3 shows the immunofluorescence images of chromaffin cells identified by double or triple immunostaining, in a total of 971 cells, with antinNOS and anti-TH antibodies (Fig. 3A, representative of 450 cells), anti-nNOS and anti-PNMT antibodies (Fig. 3B, representative of 396 cells) and anti-TH, anti-nNOS and anti-PNMT antibodies (Fig. 3C, representative of 125 cells).

By combining all the data from double and triple immunostainings we obtained the relative proportions of $\mathrm{NOS}^{+}$cells among adrenergic and noradrenergic populations shown in Table $1 . \mathrm{NOS}^{+}$cells comprise $53 \pm 2 \%$ of the total population (Table $1 \mathrm{~A}$ ).
NOS was preferentially expressed by noradrenergic cells $\left(82 \pm 2 \% \mathrm{NOS}^{+}\right)$, while adrenergic cells show a much lower expression of this enzyme $(26 \pm 3 \%$ $\left.\mathrm{NOS}^{+}\right)($Table 1B). The relative proportions of adrenergic and noradrenergic cells in total chromaffin cell population were $50 \pm 2 \%$ in both cases (Table 1B). This proportion was quite different in $\mathrm{NOS}^{-}$and $\mathrm{NOS}^{+}$cells; whereas in $\mathrm{NOS}^{-}$cells there was a greater proportion of adrenergic $(81 \pm 2.5 \%$, against $19 \pm 2.5 \%)$, most of $\mathrm{NOS}^{+}$cells $(76 \pm 2.5 \%)$ were noradrenergic (Table 1B).

Distribution of chromaffin cell response to nitric oxidedonors in different chromaffin cell populations

Once we had the possibility of immunoidentifying the type of chromaffin cell as either adrenergicl noradrenergic or nitrergic/non-nitrergic we were able to assign single-cell calcium responses to identified chromaffin cells.

Table 2 shows the relative proportion of NOdonor responsive cells among adrenergic and noradrenergic chromaffin cells. From a total of 125 immunoidentified chromaffin cells in which Fura-2 ratio was measured, only a $62 \pm 4 \%$ of the total population showed increases in Fura-2 ratio (Table 
A.

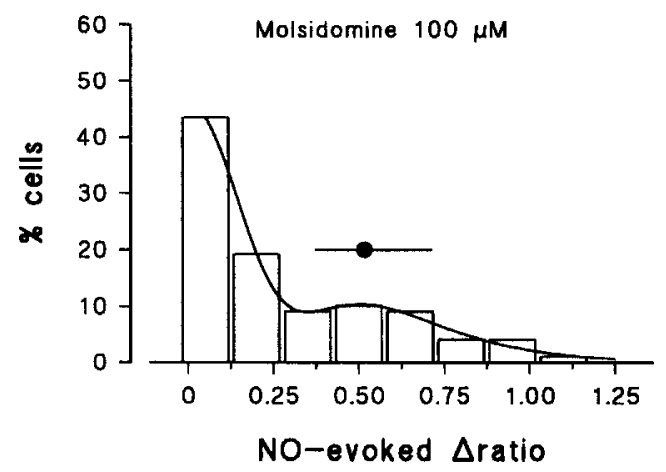

B.

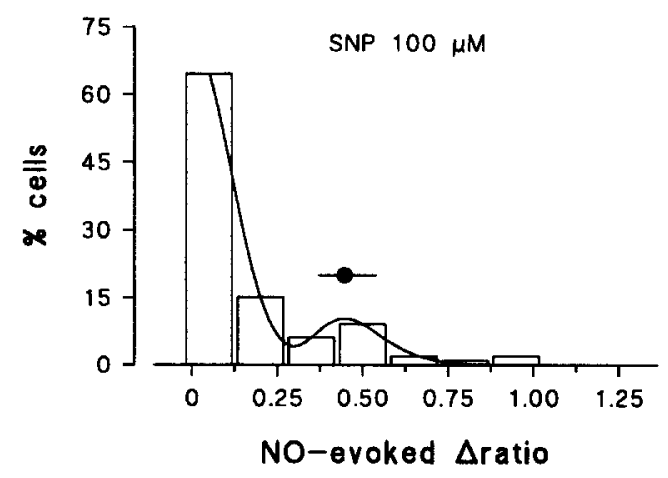

C.

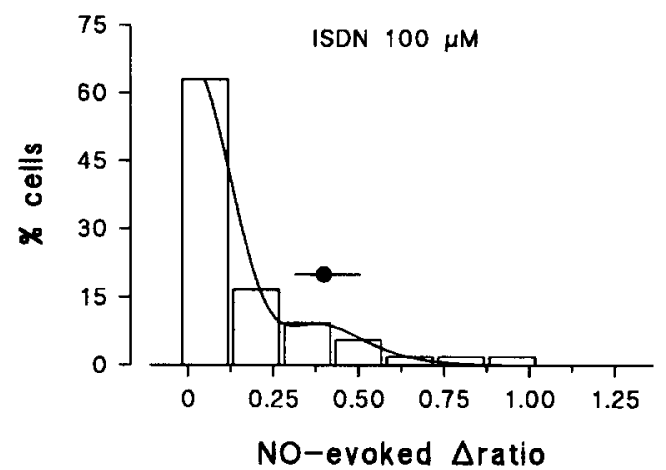

Fig. 2. Distribution of chromaffin cell Fura-2 calcium response to NO-donors in the whole chromaffin cell population. Frequency histograms show the distribution of increases in Fura-2 ratio ( $\Delta$ ratio) evoked by (A) $100 \mu \mathrm{M}$ molsidomine, (B) $100 \mu \mathrm{M} \mathrm{SNP}$ and (C) $100 \mu \mathrm{M}$ ISDN measured as indicated in Experimental Procedures. Data are results from the analysis of 125 cells of which $62 \pm 4 \%$ showed clear responses to NO-donors. First bars represent those cells unresponsive to NO donors. A log-normal distribution was fitted to the histogram representing responding cells. The average $\Delta$ ratio and \pm 2 S.D. confidence limits for mean increase are shown by the point and lines above the histograms.

2A). This proportion of NO-donor responsive cells was quite similar in adrenergic cells $(68 \pm 5 \%)$ while in noradrenergic cells the proportion was significantly reduced, only $45 \pm 9 \%$ of cells displayed increases in Fura-2 ratios (Table 2B).

Figure 4A, $B$ shows the frequency histograms reflecting the distribution of $100 \mu \mathrm{M}$ molsidomineevoked ratio increase responses in adrenergic and noradrenergic chromaffin cells. Over $60 \%$ of adrenergic cells produced positive calcium responses, while only $45 \%$ of noradrenergic cells displayed molsidomine-evoked calcium responses. However, the average increase in the ratio evoked by $100 \mu \mathrm{M}$ molsidomine was very similar in both chromaffin cell populations $(0.54 \pm 0.07$ in adrenergic and $0.57 \pm 0.12$ in noradrenergic cells). Similar results were obtained when SNP and ISDN were used as NO-donors (data not shown). NO-responsive cells were not differentially segregated to $\mathrm{NOS}^{+}$and $\mathrm{NOS}^{-}$chromaffin cells. The proportions of NO-responding cells were $63 \pm 5 \%$ and $60 \pm 7 \%$ for $\mathrm{NOS}^{+}$and $\mathrm{NOS}^{-}$cells, respectively (Table 2C). However, the averaged ratio increases elicited by molsidomine in $\mathrm{NOS}^{+}$ and $\mathrm{NOS}^{-}$cells were significantly higher in $\mathrm{NOS}^{-}$ cells $(0.48 \pm 0.07$ and $0.65 \pm 0.06$, respectively; Fig. 5A, B).

The results of analysing all the data for the three NO-donors show the relative proportions of NOdonor-responsive cells among $\mathrm{NOS}^{+}$and $\mathrm{NOS}^{-}$and between adrenergic and noradrenergic chromaffin cells to be that indicated in Table 3. No significant difference exists between the adrenergic $(59 \pm 8 \%)$, noradrenergic $(67 \pm 16 \%)$ and total population $(60 \pm 7 \%)$ of $\mathrm{NOS}^{-}$chromaffin cells while the relative proportion of NO-donor-responsive cells was significantly smaller in noradrenergic population of NOS $^{+}$chromaffin cells (35 $\pm 11 \%$ against $73 \pm 6 \%$ in noradrenergic and adrenergic cells, respectively).

\section{DISCUSSION}

Previous studies on the effects of NO in chromaffin or PC-12 cells have focused mainly on the effects on secretagogue-evoked catecholamine secretion or $\left[\mathrm{Ca}^{2+}\right]_{\mathbf{i}}$ increases. ${ }^{6,32,33,36}$ Less attention has been paid to the direct action of NO on basal catecholamine secretion and $\left[\mathrm{Ca}^{2+}\right]_{i}$, an effect in which the NO may be considered more as a primary neurotransmitter than a neuromodulator. This point appears to be somewhat controversial. Dohi et al., working on perfused dog adrenals, described a stimulatory effect of nitro-compounds, including NO, in catecholamine secretion, but this enhancement of catecholamine release was not observed in perfused cat adrenal medulla ${ }^{24}$ nor in bovine cultured chromaffin cells. ${ }^{29}$ Here we have demonstrated that NOdonors elicit clear $\left[\mathrm{Ca}^{2+}\right]_{\mathrm{i}}$-increasing responses in bovine chromaffin cells in culture. Since $\mathrm{Ca}^{2+}$ is the direct trigger for catecholamine release, this result supports our previous finding that NO gas can elevate basal catecholamine secretion. ${ }^{27}$ The $\left[\mathrm{Ca}^{2+}\right]_{i}$ increase elicited by NO donors was modest when compared with the responses to nicotine, but in 
A.

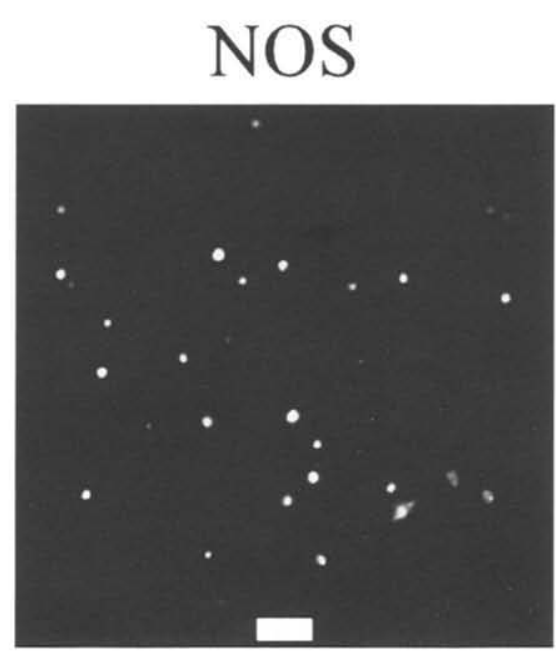

B.

NOS

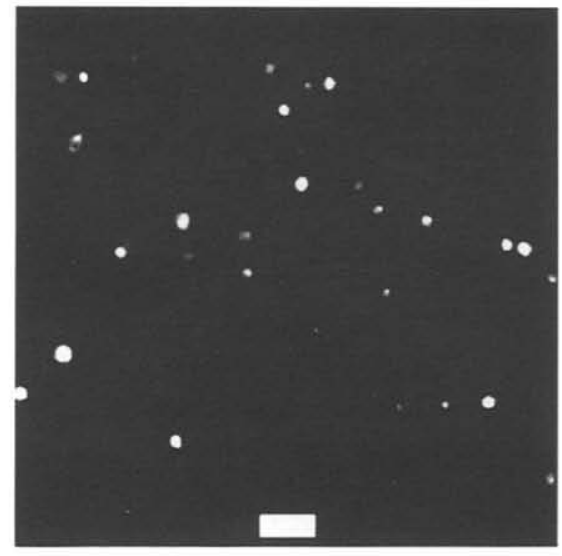

TH

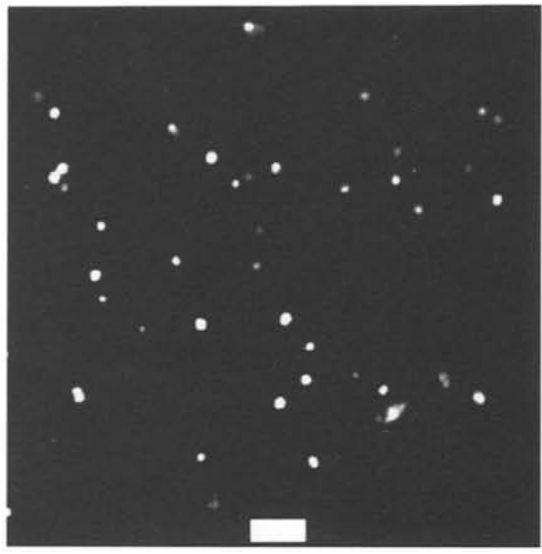

PNMT

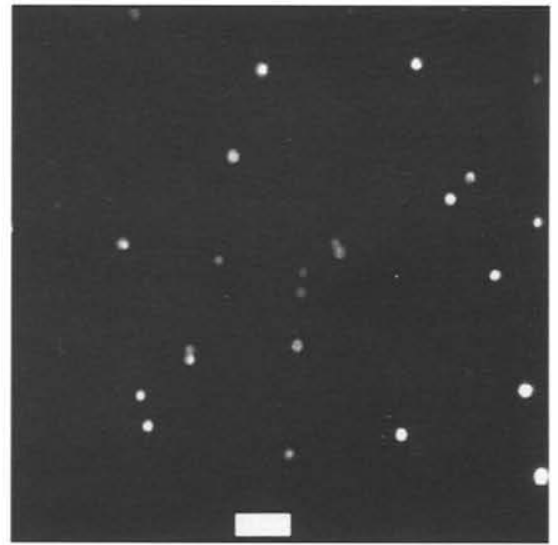

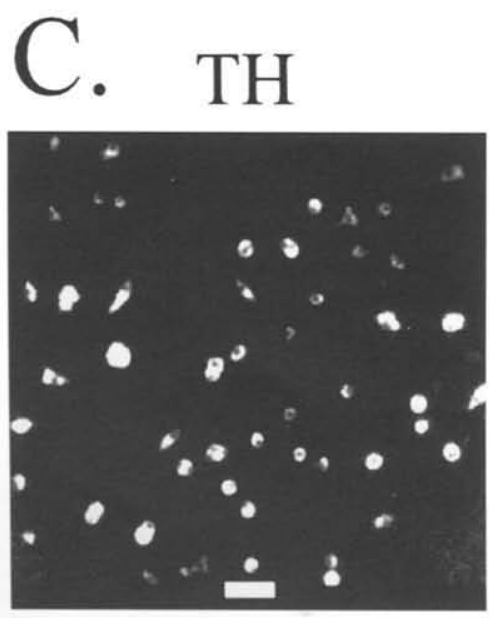

NOS

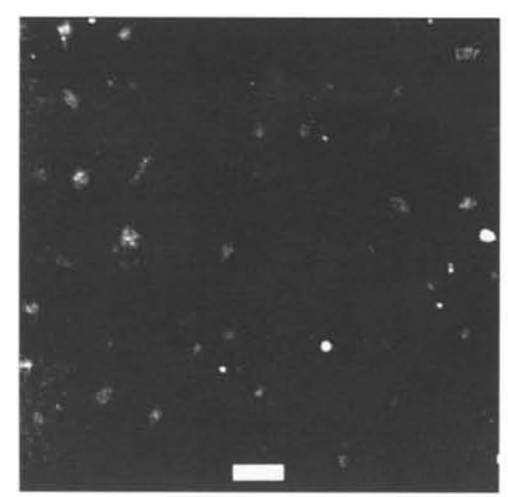

Fig. 3.
PNMT

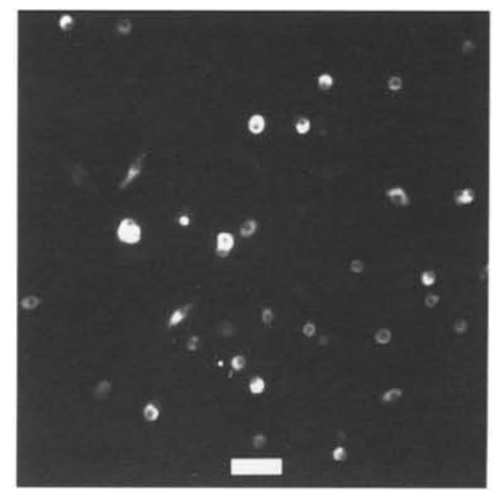


Table 1. Relative proportion of nitric oxide synthase-positive and negative cells in the whole chromaffin cell population (A) and within adrenergic and noradrenergic subpopulations (B)

\begin{tabular}{|c|c|c|c|c|c|c|}
\hline & \multicolumn{2}{|c|}{$\mathrm{NOS}^{+}$} & \multicolumn{2}{|c|}{$\mathrm{NOS}^{-}$} & \multirow{2}{*}{$\frac{\text { Total }}{n}$} & \\
\hline & $n$ & $\%$ & $n$ & $\%$ & & \\
\hline $\begin{array}{l}\text { (A) Whole population } \\
\text { (B) Adrenergic cells } \\
\text { Noradrenergic cells } \\
\text { (total) }\end{array}$ & $\begin{array}{r}512 \\
69 \\
213 \\
282\end{array}$ & $\begin{array}{l}53 \pm 2 \\
26 \pm 3(13) \\
82 \pm 2(42) \\
54 \pm 2\end{array}$ & $\begin{array}{r}459 \\
193 \\
46 \\
239\end{array}$ & $\begin{array}{l}47 \pm 2 \\
74 \pm 3(37) \\
18 \pm 2(9) \\
46 \pm 2\end{array}$ & $\begin{array}{l}971 \\
262(50 \pm 2) \\
259(50 \pm 2) \\
521\end{array}$ & $\begin{array}{c}P<0.001 \\
P<0.001 \\
(P<0.001)\end{array}$ \\
\hline
\end{tabular}

The values within parenthesis are percentages calculated from the whole population. Data combining results from the three approaches indicated in Fig. 3. Collected from seven separate experiments and counting 22 independent microscopic fields. Statistical analysis: \pm values were calculated as S.D. for a binomial distribution with the observed proportions. $P$ values to the right represent testing the individual binomial proportion in each line against the $53 \%$ proportion observed in A. $P$ value at the bottom right (in brackets) is the result of a $\chi^{2}$-test for equal distribution of NOS in adrenergic and noradrenergic cells.

Table 2. Relative proportion of chromaffin cells responding to nitric oxide donors with a $\left[\mathrm{Ca}^{2+}\right]_{i}$ increase in: (A) whole population; (B) adrenergic and noradrenergic cells and (C) nitric oxide synthase-positive and negative subpopulations of chromaffin cells

\begin{tabular}{|c|c|c|c|c|c|c|}
\hline & \multicolumn{2}{|c|}{$\left[\mathrm{Ca}^{2+}\right]_{i}$-responsive } & \multicolumn{2}{|c|}{$\left[\mathrm{Ca}^{2+}\right]_{i}$-unresponsive } & \multirow[b]{2}{*}{ total } & \\
\hline & $n$ & $\%$ & $n$ & $\%$ & & \\
\hline $\begin{array}{l}\text { (A) Whole population } \\
\text { (B) Adrenergic cells }\end{array}$ & $\begin{array}{l}78 \\
65\end{array}$ & $\begin{array}{l}62 \pm 4 \\
68 \pm 5\end{array}$ & $\begin{array}{l}47 \\
31\end{array}$ & $\begin{array}{l}38 \pm 4 \\
32 \pm 5\end{array}$ & $\begin{array}{r}125 \\
96\end{array}$ & \\
\hline $\begin{array}{l}\text { Noradrenergic cells } \\
\text { (C) } \mathrm{NOS}^{+} \text {cells }\end{array}$ & $\begin{array}{l}13 \\
52\end{array}$ & $\begin{array}{l}45 \pm 9 \\
63 \pm 5\end{array}$ & $\begin{array}{l}16 \\
30\end{array}$ & $\begin{array}{l}55 \pm 9 \\
37 \pm 5\end{array}$ & $\begin{array}{l}29 \\
82\end{array}$ & \\
\hline $\operatorname{NOS}^{-}$cells & 26 & $60 \pm 7$ & 17 & $40 \pm 7$ & 43 & \\
\hline
\end{tabular}

Data collected from nine different stimulations in three separate experiments. The observed difference between adrenergic and noradrenergic cells was significant as judged from a $\chi^{2}$-test. N.S., non-significant.

proportion with the relatively smaller effect of NO on catecholamine secretion. In agreement with this view, the treatment of chromaffin cells with an analogue of cGMP, the proposed second messenger for NO actions, elicited a small increase in $\left[\mathrm{Ca}^{2+}\right]_{\mathrm{i}}{ }^{32} \mathrm{By}$ using Fura-2 imaging techniques we have been able to reveal the heterogeneity of single cell responses to NO donors. Not all cells in a given culture displayed $\left[\mathrm{Ca}^{2+}\right]_{\mathrm{i}}$ rises elicited by NO-donors. Furthermore, the time course of $\left[\mathrm{Ca}^{2+}\right]_{i}$ was highly variable, both in the onset and pattern of the response. Part of this variability may reside in the different kinetics of NO release by the NO-donors used. In fact, the response to nicotine, a direct agonist of acetylcholine receptors, occurred almost in synchrony in all cells. This heterogeneity, together with the fact that only a subpopulation $(62 \pm 4 \%)$ of chromaffin cells responded to NO donors with $\left[\mathrm{Ca}^{2+}\right]_{i}$ risés may explain why this effect has been elusive to others.

Bovine chromaffin cells in culture are a very popular model for the study of neurosecretion. In contrast to other species like guinea-pigs or chickens, bovine adrenal medulla contains both adrenergic and noradrenergic chromaffin cells. Although the adrenergic component predominates in the intact gland (around $70 \%$ ), the proportion of adrenergic and noradrenergic cells in cultures varies with the method used for cell dissociation and purification. ${ }^{23}$ Several studies have indicated that the distribution of receptors for $\mathrm{ATP}{ }^{4}$ histamine, ${ }^{5,26}$ angiotensin $\mathrm{II}^{26}$ or $\mathrm{GABA}^{28}$ is differentially segregated to adrenergic or noradrenergic cells. Thus the question arises as

Fig. 3. Immunofluorescence images showing the identification of chromaffin cells by specific enzymatic antibodies. Chromaffin cells were identified by immunostaining with specific antibodies as indicated in Experimental Procedures. (A) Double immunostaining of chromaffin cells with antibodies anti-TH (total population) and anti-nNOS (nitrergic cells). (B) Double immunostaining of chromaffin cells with antibodies anti-PNMT (adrenergic cells) and anti-nNOS (nitrergic cells). (C) Triple immunostaining of chromaffin cells with antibodies anti-TH (total population), PNMT (adrenergic cells) and anti-nNOS (nitrergic cells). In B and C, noradrenergic cells are stained by anti-TH but not by anti-PNMT antibodies. The plates are representative of several experiments, amounting to a total of 971 analysed cells. Scale bars $=50 \mu \mathrm{m}$. 
A.

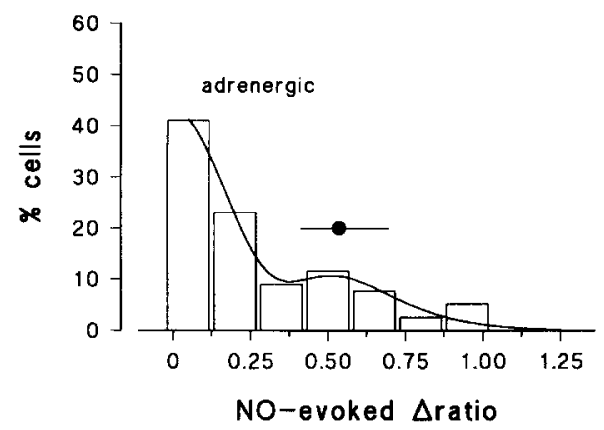

B.

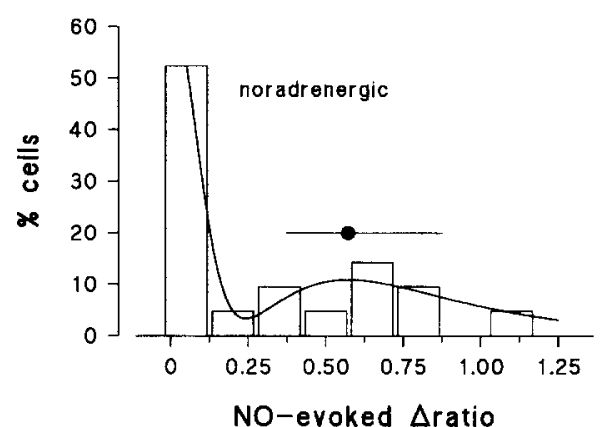

Fig. 4. Distribution of chromaffin cell response to NOdonors in whole, adrenergic and noradrenergic chromaffin cell populations. (A, B) Frequency histograms showing the distribution of $100 \mu \mathrm{M}$ molsidomine evoked $\Delta$ ratio responses in adrenergic and noradrenergic chromaffin cells. The average increase in the ratio was very similar in both chromaffin cell populations. The response was not significantly higher in any of these subpopulations (Student's $t$-test).

to whether NO responses are correlated to the adrenergic/noradrenergic or $\mathrm{NOS}^{+} / \mathrm{NOS}^{-}$phenotype of chromaffin cells. Immunoidentification of NOresponsive cells revealed that they were relatively more frequent among adrenergic cells than among noradrenergic cells. In the same way, the expression of NOS was not an unambiguous marker for the identification of NO-responsive cells, although $\left[\mathrm{Ca}^{2+}\right]_{\mathrm{i}}$ responses to NO donors were more frequent among $\mathrm{NOS}^{-}$cells. As a result of the cumulative bias of the distribution of responses to NO donors in adrenergic/noradrenergic and $\mathrm{NOS}^{+} / \mathrm{NOS}^{-}$cells, NO-evoked $\left[\mathrm{Ca}^{2+}\right]_{\mathrm{i}}$ transients were significantly less abundant among $\mathrm{NOS}^{+}$noradrenergic cells. Thus, the proportion of adrenergic/noradrenergic cells (as well as $\mathrm{NOS}^{+} / \mathrm{NOS}^{-}$cells) in a mixed population could significantly affect the average signal elicited by NO donors.

In contrast to the incomplete segregation of responses to NO donors, we show here a clearly asymmetric distribution of NOS immunoreactivity among adrenergic and noradrenergic cells. NOS immunoreactivity is mainly $(82 \pm 2 \%)$ localized in PNMT $^{-}$chromaffin cells, despite noradrenergic cells
A.

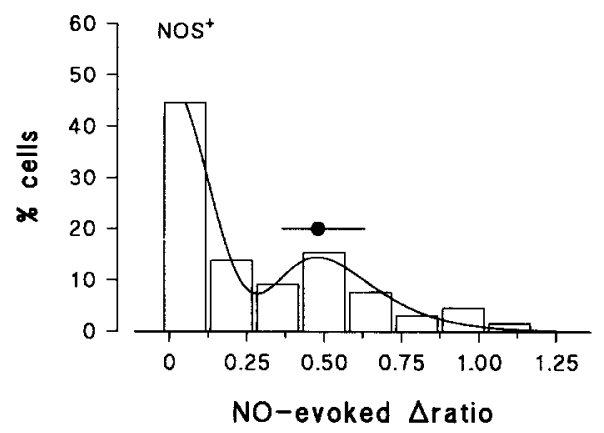

B.

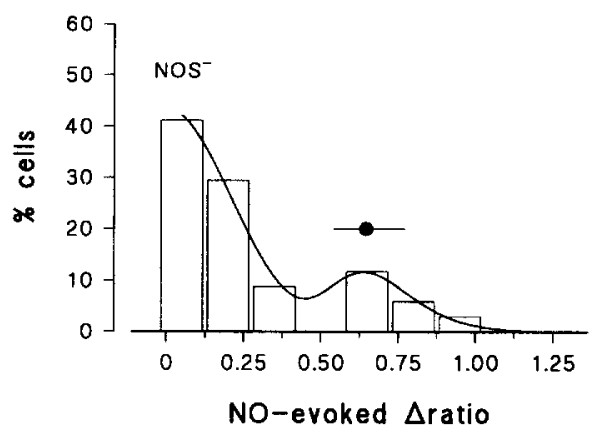

Fig. 5. Distribution of NO-donor-responsive cells between NOS $^{+}$and NOS $^{-}$chromaffin cells. (A, B) Frequency histograms showing the distribution of $100 \mu \mathrm{M}$ molsidomine evoked increases in $\Delta$ ratios in $\mathrm{NOS}^{+}$and $\mathrm{NOS}^{-}$chromaffin cells. The average ratio increase was significantly higher in $\mathrm{NOS}^{-}$chromaffin cells $(P<0.01$; Student's $t$-test $)$.

Table 3. Distribution of nitric oxide-donor responsive cells among nitric oxide synthase-positive/negative and adrenergic/noradrenergic chromaffin cells

\begin{tabular}{llll}
\hline & Adrenergic & Noradrenergic & \\
\hline NOS $^{+}$ & $73 \pm 6 \%(45 / 62)$ & $35 \pm 11 \%(7 / 20)$ & $P<0.05$ \\
NOS $^{-}$ & $59 \pm 8 \%(20 / 34)$ & $67 \pm 16 \%(6 / 9)$ & N.S. \\
\hline
\end{tabular}

Data collected from nine different stimulations in three independent experiments. Statistical analysis: S.D. values were obtained assuming a binomial distribution. The whole table was tested for equal proportion hypothesis by both ANOVA and a Pearson $\chi^{2}$-test. Both tests gave significant results at $P=0.05$, indicating unequal distribution of NO-donor responsive cells. $P$ values quoted correspond to a within-rows $\chi^{2}$-test. Results in parenthesis represent the number of responding cells against the total cell number $(n=125$ cells).

being in lower number than adrenergic cells in the bovine adrenal gland. This result agrees with and extends previous data indicating that NOS was present only in a subpopulation of chromaffin cells in human ${ }^{15}$ and, not so clearly, in rat adrenal medulla. ${ }^{9}$ These results point out that the information flow carried by NO within adrenal medulla travels mainly from noradrenergic cells (most $\mathrm{NOS}^{+}$cells are 
$\mathrm{PNMT}^{-}$) to adrenergic cells (they are more abundant and mostly $\mathrm{NOS}^{-}$and responsive to NO donors). In other words, NO may have a paracrine role, with noradrenergic cells specialized in the synthesis of NO whereas adrenergic cells constitute mainly the target of NO action. This view is stressed considering the short life and range of action of NO in a well-irrigated tissue like adrenal medulla.

\section{CONCLUSION}

Our results emphasize the importance of studying even relatively simple systems such as adrenomedul- lary cultures at the cellular level and highlights the functional importance of chromaffin cell heterogeneity in relation to $\mathrm{NO}$ actions.

Acknowledgements - This study was supported by the grant FIS 95/1537 from Fondo de Investigaciones Sanitarias of Madrid (Ministry of Health, Spain). E.C. was supported by a FEBS Long Term fellowship. M.J.O.G. was recipient of a short-term fellowship from UCM (Spain). We thank Angelo Tomé and Graça Baltazar from the Institute of Neurosciences of Coimbra for their help in obtaining chromaffin cell cultures. We also thank Duncan A. Gilson for his help correcting the manuscript.

\section{REFERENCES}

1. Aoki E., Takeuchi I. K., Shoji R. and Sema R. (1993) Localization of nitric oxide-related substances in the peripheral nervous tissues. Brain Res. 620, 142-145.

2. Bagetta G., Corasaniti T., Malino G., Paoletti A. M., Finazzi-Agrò A. and Nisticò G. (1993) Lithium and tacrine increase the expression of nitric oxide synthase mRNA in the hippocampus of rat. Biochem. biophys. Res. Commun. $197,1132-1139$.

3. Bredt D. S., Hwang P. M. and Snyder S. H. (1990) Localization of nitric oxide synthase indicating a neural role for nitric oxide. Nature $347,768-770$.

4. Castro E., Mateo J., Tomé A. R., Barbosa R. M., Miras-Portugal M. T. and Rosário L. M. (1995) Cell-specific purinergic receptors coupled to $\mathrm{Ca}^{2+}$ entry and $\mathrm{Ca}^{2+}$ release from internal stores in adrenal chromaffin cells. $J$, hiol. Chem. 270, 5098-5106.

5. Choi A. Y., Cahill A. L., Perry B. D. and Perlman R. L. (1993) Histamine evokes greater increases in phosphatidylinositol metabolism and catecholamine secretion in epineprine-containing than in norepineprinecontaining chromaffin cells. J. Neurochem. 61, 541-549.

6. Clementi E., Vecchio Y., Sciorati C. and Nisticò G. (1995) Nitric oxide modulation of agonist-evoked intracellular $\mathrm{Ca}^{2+}$ release in neurosecretory PC-12 cells: inhibition of phospholipase $\mathrm{C}$ activity via cyclic GMP-dependent protein kinase I. Molec. Pharmac. 47, 517-524.

7. Dohi T., Morita K. and Tsujimoto A. (1983) Effect of sodium azide on catecholamine release from isolated adrenal gland and on guanylate cyclase. Eur. J. Pharmac. 94, 331-335.

8. Duarte C. B., Tome A. R., Forsberg E., Carvalho C. A. M., Carvalho A. P., Santos R. M. and Rosario L. M. (1993) Neomycin blocks dihydropyridine-insensitive $\mathrm{Ca}^{2+}$ influx in bovine adrenal chromaffin cells. Eur. J. Pharmac. 244, $259-267$

9. Dun N. J., Dun S. L., Wu S. Y. and Förstermann U. (1993) Nitric oxide synthase immunoreactivity in rat superior cervical ganglia and adrenal glands. Neurosci. Lett. 158, 51-54.

10. Fujita T., Kanno T. and Kobayashi S. (1988) In The Paraneuron, pp. 135-144. Springer, Tokyo.

11. Haby C., Lisovoski F., Aunis D. and Zwiller J. (1994) Stimulation of the cyclic GMP pathway by NO induces expression of the immediate early genes c-fos and jun B in PC-12 cells. J. Neurochem. 62, 496-501.

12. Haley J. E., Wilcox G. L. and Chapman P. F. (1992) The role of nitric oxide in hippocampal long-term potentiation. Neuron 8, 211-216

13. Hanbauer 1. (1993) The role of nitric oxide in neurotransmitter release. In Nitric Oxide: Brain and Immune System (eds Moncada S., Nistico G. and Higgs E. A.), pp. 135-141. Portland Press, London.

14. Harlow E. and Lane D. (1988) Antibodies: A Laboratory Manual. Cold Spring Harbor Laboratory, Cold Spring Harbor, U.S.A.

15. Heym C., Colombo-Benckmann M. and Mayer B. (1994) Immunohistochemical demonstration of the synthesis enzyme for nitric oxide and of comediators in neurons and chromaffin cells of the human adrenal medulla. Ann. Anat. 176, $11-16$

16. Holgert H., Aman K., Cozzari C., Hartman B. K., Brimijoin S., Emson P., Goldstein M. and Hökfelt T. (1995) The cholinergic innervation of the adrenal gland and its relation to enkephalin and nitric oxide synthase. NeuroReport 6 , $2576-2580$.

17. Kuijpers G. A., Rosario L. M. and Ornberg R. L. (1989) Role of intracellular pH in secretion from adrenal medulla chromaffin cells. J. biol. Chem. 264, 698-705.

18. Marletta M. A. (1993) Nitric oxide synthase structure and mechanism. J. biol. Chem. 268, 12,231-12,234

19. McPherson G. (1990) Statistics in Scientific Investigation: Its Basis, Application and Interpretation, pp. $181-198$ and 446 474. Springer, New York.

20. Marley P. D., McLeod J., Anderson C. and Thomson K. A. (1995) Nerves containing nitric oxide synthase and their possible function in the control of catecholamine secretion in the bovine adrenal medulla. $J$. auton. nerv. Syst. 54, 184-194.

21. Miller R. J. (1992) Neuronal $\mathrm{Ca}^{2+}$ : getting it up and keeping it up. Trends Neurosci. 15, 317-319.

22. Moncada S., Palmer R. M. J. and Higgs E. A. (1991) Nitric oxide: physiology, pathophysiology and pharmacology. Pharmac. Rev. 43, 109-142.

23. Moro M. A., Garcia A. G. and Langley O. K. (1991) Characterization of two chromaffin cell populations isolated from bovine adrenal medulla. $J$. Neurochem. 57, 363-369.

24. Moro M. A., Michelena P., Sánchez-García P., Palmer R., Moncada S. and García A. G. (1993) Activation of adrenal medullary L-arginine:nitric oxide pathway by stimuli which induce the release of catecholamines. Eur. J. Pharmac. 246, 213-218. 
25. Nathan C. F. and Hibbs J. B. Jr (1991) Role of nitric oxide synthesis in macrophage antimicrobial activity. Curr. Opin. Immunol. 3, 65-70.

26. Núñez L., De la Fuente M. T., García A. G. and García-Sancho J. (1995) Differential Ca ${ }^{2+}$ responses of adrenergic and noradrenergic chromaffin cells to various secretagogues. Am. J. Physiol. 269, C1540 C1546.

27. Oset-Gasque M. J., Parramón M., Hortelano S., Boscá L. and González M. P. (1994) Nitric oxide implication in the control of neurosecretion by chromaffin cells. $J$. Neurochem. 63, 1693-1700.

28. Oset-Gasque M. J., Castro E., González M. P. and Rosario L. M. (1995) Differential functional response of adrenergic and noradrenergic bovine chromaffin cells to GABA. In 8th International Symposium on Chromaffin Cell Biology, Edinburgh, Scotland, August, P52, p. 123.

29. O'Sullivan A. J. and Burgoyne R. D. (1990) Cyclic GMP regulates nicotine-induced secretion from cultured bovine adrenal chromaffin cells: effects of 8-bromo-cyclic GMP, atrial natriuretic peptide and nitroprusside (nitric oxide). J. Neurochem. 54, 1805-1808.

30. Palacios M., Knowles R. G., Palmer R. M. J. and Moncada S. (1989) Nitric oxide from L-arginine stimulates the soluble guanylate cyclase in adrenal glands. Biochem. hiophys. Res. Commun. 165, 802-809.

31. Peunova N. and Enikolopov G. (1993) Amplification of calcium-induced gene transcription by nitric oxide in neuronal cells. Nature 364, $450-453$.

32. Rodriguez-Pascual F., Miras-Portugal M. T. and Torres M. (1995) Cyclic GMP-dependent protein kinase activation mediates inhibition of eatecholamine secretion and $\mathrm{Ca}^{2+}$ influx in bovine chromaffin cells. Neturoscience 67, $149-157$.

33. Rodriguez-Pascual F., Miras-Portugal M. T. and Torres M. (1996) Effect of cyclic GMP-increasing agents nitric oxidc and c-type natriuretic peptide on bovine chromaffin cell function: inhibitory role mediated by cyclic GMP-dependent protein kinase. Molec: Pharmac: 49, 1058-1070.

34. Snedecor G. W. and Cochran W. G. (1967) Statistical Methods 6th edn, pp. 251-284 and pp. 573-610. lowa State University Press, Ames, Iowa.

35. Teraoka H., Sugawara T. and Nakazato Y. (1993) Difference in the effectiveness of $\mathrm{Ca}^{2+}$ to evoke catecholamine secretion between adrenaline- and noradrenaline-containing cells of bovine adrenal medulla. J. Neurochem. 60, $1936-1940$.

36. Uchiyama Y., Morita K.. Kitayama S., Suemitsu T., Minami N., Miyasako T. and Dohi T. (1994) Possible involvement of nitric oxide in acetylcholine-induced increase of intracellular $\mathrm{Ca}^{2+}$ concentration and catecholaminc release in bovine adrenal chromaffin cells. Jap. J. Pharmac: 65, 73-77.

37. Zhang J., Dawson V. L., Dawson T. M. and Snyder S. H. (1994) Nitric oxide activation of poly(ADPribose)synthethase in neurotoxicity. Science 263, 687-689. 